\title{
WORKING CLASS IN POST-SOCIALIST TRANSFORMATION: SERBIA AND CROATIA COMPARED
}

\author{
MLADEN LAZIĆ' ${ }^{1}$ SLOBODAN CVEJIĆ ${ }^{2}$
}

\begin{abstract}
Serbia and Croatia, both actors in civil wars during the 1990s, started their transformation by emerging from the same model of "liberal socialism". The two countries had authoritarian regimes with nationalistic mobilization, and their respective transformations developed under the control of their political oligarchies. In addition to many similarities, there are also important differences which influenced their transformations. Croatia embarked upon its modernization earlier than Serbia, and was more developed economically. In contrast to Serbia, which suffered international political and economic isolation during the 1990s, Croatia enjoyed external support (making it more susceptible to external influences, to some extent) and moreover, was more opened to the world economically. This resulted in a faster economic recovery for Croatia, and accounts for the country's substantially more favorable position in the EU integration processes. Based on joint research carried out in 1989 and 2003, this paper tries to establish the degree of influence of the stated similarities and differences on changes in position of the working class in these countries, and moreover, on class homogeneity (measured in terms of economic differentiation, vertical mobility, value orientations, and trade union and political organization).
\end{abstract}

KeYwords Serbia, Croatia, working class, fragmentation, mobility, economic position, political orientations

\footnotetext{
1 Mladen Lazić is professor of Sociology at the Faculty of Philosophy, Belgrade; e-mail: bigalazi@eunet.rs

2 Slobodan Cvejić is professor of Sociology at the Faculty of Philosophy, Belgrade; e-mail: scvejic@sbb.rs
} 


\section{INTRODUCTION}

This paper will seek to show the types of changes within the working class during the post-socialist transformation. These will be analyzed comparatively in Serbia and Croatia, for both cognitive and methodological purposes. The two countries started their respective transformations by emerging from the same model of "liberal socialism", and were actors in the war in the territories of the former SFRY during the 1990s. Furthermore, throughout that decade, both states had authoritarian regimes based on nationalist mobilization, and their transformations were fully controlled by their ruling political oligarchies. However, along with these similarities, there were also important differences that doubtlessly influenced their transformation. Croatia entered modernization processes somewhat earlier than Serbia and was, economically, substantially more developed in the late 1980s. Moreover, in contrast to Serbia, which spent a good part of the 1990s under international political and economic isolation, sanctions, etc., Croatia enjoyed international political support (which made it more susceptible to external influences), and was also more open to the world economically. This resulted in Croatia's faster economic recovery, and accounts for the country's much more favorable position in EU integrations. The attempt to establish the degree of influence of the abovementioned (and numerous other) similarities and differences on the change in position of the working class in these countries, and primarily on class homogeneity, will use the methodological advantage offered by the results of two joint cross-sectional surveys, the first of which was carried out on the eve of the breakdown of the socialist order in 1989, and the second at the time of a relatively stabilized transformation in both countries in $2003 .^{3}$

The central concept of the analysis is class fragmentation. Class fragmentation, for us, denotes deep and intersecting divisions developed within a certain class along different dimensions - including economic positions, recruitment patterns, organizational forms, and value orientations - thus precluding or substantially aggravating and limiting, collective class action for the protection and promotion of its own class interests. In this sense, the concept of fragmentation is opposed to that of class homogeneity, which represents a basic unity of class characteristics displayed by members

\footnotetext{
3 The first survey, "Structure and Quality of Life", was carried out on a sample of over 14,000 respondents in all republics of the former Yugoslavia, and was organized by a Consortium of social sciences institutes. The second survey, "South East European Social Survey Project", with a sample of over 22,000 respondents in Albania, Bosnia and Herzegovina, Montenegro, Croatia, Macedonia, Kosovo, and Serbia, was organized by Tromsø University (Norway) and funded by the Government of the Kingdom of Norway.
} 
of a social group, which is established on the basis of the group's position in the reproduction of the social order, and which create the preconditions for the group to appear as a collective actor in the processes of social change. For the purpose of these considerations, the concept of the working class shall be understood in a narrow sense, including only manual workers unskilled and skilled - without managerial authorities in the work process, or with a minimum of such authorities (foremen) in privately- and state-owned enterprises and institutions in three sectors of the economy: agriculture, industry, and services.

\section{WORKING CLASS HOMOGENEITY IN TIMES OF YUGOSLAV SOCIALISM}

The key characteristic of the socialist type of society was the totalized management of the overall social reproduction by the ruling collective-owner class (nomenklatura) (cf. Lazić 1987; Feher et al. 1984). This means that the centrally-planned command control covered all social sub-systems, including the spheres of economy, politics, and ideology. The abolishment of private ownership, along with the market economy, also removed the freedom to dispose of one's own work, while the introduction of a one-party monopoly excluded the possibility of the specific representation of the workers' class interests on both the political and trade-union levels, and ideological dictatorship imposed a uniformity of worldview. A direct consequence of the totalized control over society was the complete atomization of all social groups outside the nomenklatura, thus including the workers (Lazić 1987). These social losses were, however, partly offset by reduced economic disparities, not only between different categories of the employed, but also in society in general, as well as with practically full employment under conditions of accelerated modernization (industrialization, deagrarization, expansion of the educational system, etc.: for the SFRY, see empirical findings in Berković 1986; Popović ed. 1987; Lazić 1994).

These "model" characteristics of socialism also prevailed in Yugoslav society $^{4}$, twenty-odd years after World War II, although the mid-1960s marked the beginning of reforms which will, in the forthcoming period, denote this society as "market-oriented", "self-managerial", "liberal", and "open." There were basically two causes for the reform of Yugoslav socialism: due to the 4 Further references to the SFRY shall imply general systemic characteristics shared by Serbia
and Croatia until the end of the 1980s.

CORVINUS JOURNAL OF SOCIOLOGY AND SOCIAL POLICY 1 (2010) 
conflict with the USSR the communist leadership needed a new basis for legitimacy, and its members looked for it in the "original Marxist" idea of the workers' direct management of production. This change, however, remained only nominal during the 1950s, until a new factor entered the scene: the economic crisis of the early 1960 s, which the nomenklatura tried to redress with decentralization: limited transfer of managerial authorities in enterprises from central planning bodies to managers (Sekelj 1990). Thus the first ideological pattern merged with the other, practical-organizational, to form a "self-management economy" as a specific characteristic of the Yugoslav order.

"Workers' self-management" had two crucial limitations. First of all, the sum of managerial authorities, transferred to enterprises, depended on arbitrary decisions taken at higher levels of the nomenklatura, and was changeable (subject to political conflicts within the ruling strata as well as economic trends), and invariably very limited (the nomenklatura retained final control: over enterprises' funds, through the oversight of the banking system; and over personnel through the party line). Furthermore, in the enterprises themselves, power was largely concentrated in the hands of their managers, while the workers' councils (and especially their members from the ranks of manual workers) had minimal influence in decision-making (Županov 1983; Arzenšek 1984; Rus - Adam 1989). The consequences of these contrasts - between centralized command authorities and decentralization, as well as between the command nature of the order and its self-management legitimacy - were multiple, of which only a few of the most important will be mentioned here. The first contraposition enabled the Yugoslav economy to assume certain quasi-market features (a market for consumer goods, a limited labor market), and to be partially included in the world economy (Slovenia's economy was an example of a successful "transition" to a liberal economy during the 1990s). It, however, also encouraged constant conflicts between the republic nomenklaturas for the control of "their own" economies (ending in a tragic civil war), as well as conflicts between political and managerial elites with the frequent result that the initiated economic reforms, and even political-cultural liberalization, were abandoned.

But, here we are primarily interested in the consequences of the abovementioned systemic opposites related to the position of the working class. The new (self-management) legitimacy pattern, along with economic decentralization, changed the main economic orientation of Yugoslav socialism by introducing consumption as an objective equal to accumulation (for accumulation as the primary goal of socialist production, see Madžar 1990; Berend 1996). That substantially increased the living standard of all 
the basic social groups, including manual workers. Then, (quasi-market) decentralization heightened economic differentiation at several levels: between managerial, middle, and worker strata (cf. Lazić ed. 1994), between territorial units (republics, provinces - cf. Berković 1986), as well as between different branches of the economy, and even enterprises within the same branch (Korošić 1983). In this way, the systemically atomized workers were now multiply fragmented, since their economic position and related interests were essentially dependent on the work they did (the enterprise they were employed in, the branch of economy, republic, etc.). Furthermore, quasimarket economic reforms during the 1960s gained substantial momentum precisely in the labor market, enabling managers to start with large layoffs of "redundancies," resulting in the dramatic growth of unemployment and a heavy outflow - primarily of manual workers - to Western countries. Thus a new form of fragmentation emerged, based on the division between the employed and unemployed.

The effects of fragmentation were made particularly visible by workers' strikes which had already started breaking out in Yugoslav enterprises in the 1950s and which were massively attended in the late 1960s, in parallel with the ascent of self-management as the basis of legitimacy of the order. That precisely and clearly revealed the previously-mentioned contrariety of the Yugoslav institutional and legitimacy systems. The fact that the workers were actually deprived of the possibility for "self-management" compelled them to resort to strikes outside the institutions in order to protect their interests. On the other hand, the strikers could not be subject to repressive measures because "work stoppages" were interpreted as the "self-management right" of the employed. But, in this context, class fragmentation was manifested in the reality that neither the mass attendance of strikes, nor their public nature (generally reported in the media during the 1970s and 1980s), could lead to the joining of individual conflicts into a wider workers' movement. Not only did the employees of a specific enterprise fail to show solidarity with those in another - within the same branch, or territory, for example - but in most cases strikes were mounted in only a part of an enterprise, and manual laborers were practically never joined by non-manual workers, including even those with the lowest incomes in the company concerned (Jovanov 1979; Jovanov 1983). Naturally, the fact that the ruling nomenklatura retained full control over the single (centralized) trade union organization, and that the workers did not even try to form independent unions, played a very important part in precluding the possibility of translating individual class conflicts in the SFRY into a wider workers' movement.

Finally, structurally based fragmentation of the workers was, in the SFRY, 
accompanied by deep value inconsistencies. Belated capitalist modernization here resulted in the wide spread of traditionalist values (authoritarianism, patriarchalism, collectivism, egalitarianism, closure toward the world). That was, in a historical sequence, followed by the socialist command order whose basic value patterns were in many ways homologous to previous traditionalist models (Lazić 1994). In addition, rapid socialist modernization in a situation marked by a specific liberal Yugoslav model (opened to the West) introduced widespread value orientations largely opposed to the dominant values (materialism, achievement, belief in science, etc.). This, among the majority of the population, produced a confusing mixture of values, as revealed by several empirical surveys (cf. Pantić 1977; Pantić 1994). Toward the end of the 1980s, all that was followed by additional processes with further contradictory effects: growing nationalistic mobilization by political elites, which reinforced traditionalist-collectivist value patterns, and the "transitional" breakthrough of political democratization and market economics, which, externally and internally, precisely supported the opposite patterns. It is therefore small wonder that in Serbia, for example, along with a highly pronounced confusion within all social strata (cf. Lazic-Cvejic 2007), the workers, as the biggest losers both in the blocked transformation process and civil wars, were simultaneously, together with small farmers, staunchly relied upon by the regime, which blocked systemic change and pursued a war policy.

\section{DEHOMOGENIZATION OF THE WORKING CLASS IN SERBIA AND CROATIA IN THE PROCESS OF POST- SOCIALIST TRANSFORMATION}

As previously mentioned, the transformations in Serbia and Croatia display large similarities as well as important differences. These similarities and differences will be briefly reviewed in view of the importance of the specific processes for the topic of this paper. In the first place, there are differences with respect to the courses of transformation. For Serbia, this course may be divided into two periods: a period of blocked transformation (from 1989) and one of deblocking (starting late in 1996 and accelerated in 2000). It is clear that the very concept of a "blocked transformation" indicates its contradictory character (for a more extensive discussion of the concept, see Lazić ed. 2000; Lazić - Cvejić 2004). Namely, soon after the fall of the Berlin wall, systemic changes were started in Serbia by way of the introduction of political pluralism, as well as through the legalization and legitimization of 
a market economy based on private ownership. But these changes appeared to be "mandated" from above on the part of the hitherto ruling nomenklatura and unfolded under its control (exercised through retained political power), thus enabling its members to convert their previous monopolistic positions into private ownership. ${ }^{5}$ Civil war and international isolation in that period obviously created favorable conditions for changes of this kind.

In contrast to Serbia, the Socialist Democratic Party/SDP (hitherto communists) in Croatia lost the 1989 elections, but the newly established regime essentially retained the same characteristics: in a civil war situation, its authoritarian power was based on nationalistic mobilization. The necessary openness to the world in this case imposed more resolute transformation processes on the economy (privatization, restructuring, monetary-financial stabilization, etc.), but these processes in Croatia were also under the intense control of an authoritarian government. ${ }^{6}$ Thus, instead of previous positions, the largest profit in privatization was brought by "war merits", essentially reducible to serving the regime, on the basis of President Tuđman's program policy involving the necessity of creating "100 very rich families" to act as champions of market and private-ownership transformation. ${ }^{7}$ In brief, instead of two separate periods of changes, we can speak of continuity in Croatia, and the process during the 1990s developed very slowly (also under strict state control, and therefore with remarkably negative socio-economic consequences). This kind of continuity allowed for a peaceful change at the 2000 elections, which had followed Tuđman's death, and subsequently for a substantial acceleration in economic transformation as well as political transformation.

The above-mentioned factors: civil war and a highly pronounced state control over the system's transformation (in Serbia and Croatia), together

\footnotetext{
5 Results of this conversion proved extremely successful for (former) nomenklatura members, so that in the mid-1990s they accounted for about two thirds of the biggest private entrepreneurs in Serbia - cf. Lazić, in Lazić ed. 1994 (much greater than in other post-socialist countries where they constituted between a quarter and a third of the economic elite during approximately the same period - cf. Szelenyi - Szelenyi 1995).

6 By mid-1990 in Croatia “... social ownership was replaced by state control over the economy and its dominant influence" (Sekulić, 2004: 365). For more on the formation of the new economic elite in Croatia, see Sekulić 2004; Čengić ed. 2005.

7 Croatia of the 1990 s is characterized by “... marked polarization and dualization of ownership structure in the economy (the so-called economic tycoonization), i.e., the creation of a narrow stratum of a new private-owner elite directly linked with the political elite, especially in industry and banking... Even until the year 2000 the share of non-privatized state portfolio and non-consolidated and disputable ownership remained relatively high" (Čučković, 2002: 250).
} 
with international isolation accompanied by economic sanctions (in Serbia), provide the key for the understanding of working class transformation in these two countries during the 1990s. Namely, the systemic change (abolishment of command relations of social regulation) also meant the elimination of mechanisms of political, economic, and ideological monopolistic control, conducive to the enforced atomization of the class. However, neither Serbia nor Croatia made systematic and consistent efforts to introduce market (economy) and pluralistic (politics) regulatory mechanisms in their place. Privatization was pursued at a slow pace in both countries, and in Serbia in particular. ${ }^{8}$ Moreover, in view of the large drop in GDP in these two countries (which was caused by the war and, due to isolation and international trade sanctions, assumed dramatic proportions in Serbia), the economic role of the state became much greater (and more important) than its share of GDP.

The overall large drop of income made the redistributive role of the state essential for the survival of the majority of its population. A rapid decrease in wages and pensions was accompanied by rapid growth in unemployment. People from all three categories (the employed, unemployed, and pensioners) had to look for additional earnings in order to eke a bare existence, resorting to two main sources. First, the above-mentioned late modernization meant that a substantial number of the population was merely one or two generations removed from agriculture, and thus still either owned some arable land or had kin among the farmers. Therefore, one strategy of survival was the return to self-production by full or partial reversion to agricultural occupation. The second source was massive engagement in the grey or black economy, given ample room for expansion through the breakdown of the internal legal order, as well as mostly-criminalized international trade - a consequence of UN economic sanctions (Cvejić 2000; Cvejic 2002). Thus Serbia, in the early 1990s, formed quite a specific system of "triple economy": the first included the public sector with the prevailing ownership and a still more powerful regulative and distributive role for the state apparatuses, the second included the gradually developing private sector, and the third was comprised of the extremely developed sector of the grey and black economy (without either clear or stable boundaries between the legal - state and private - and paralegal and illegal economies, due to the collapse of the normative and institutional order in the country).

In contrast, the Croatian restructuring and privatization, in addition to massive layoffs, included the (early) retirement of redundant workers (with

\footnotetext{
8 Thus the growth of the private sector in the economy here resulted from the establishment of new (small- and medium-sized) enterprises much more than from ownership transformation (cf. Bolčić 2002)
} 
a substantial reduction in pensions) on a fairly large scale. ${ }^{9}$ Furthermore, in addition to "wholesale" rewards for war-time merits, a huge - and ever growing - number of (actual or ostensible) participants in the war, especially after 1995, started to receive certain economic benefits from the state. Thus pension and veterans' funds secured the once again (over) emphasized redistributive role of the state, while in addition, the impoverished population (the unemployed, pensioners, etc.) favored the rampant expansion of the grey economy until the mid-1990s. Still, even with a share as high as $25 \%$ of GDP ${ }^{10}$, it was far lower than in Serbia (where some estimates for the same period place it over $50 \%$ of GDP). In addition to that, the grey economy in Croatia has been constantly declining since the mid-1990s, and therefore would not merit a separate place in this paper.

The systemic atomization of the working class in both countries was given a strong situational incentive during the 1990s; focusing on existential selfpreservation essentially hinders wider forms of collective interest-based action. This was additionally favored by the formed authoritarian power structures (on the part of former nomenklatura members in Serbia, and the new political elite in Croatia), which included the control over trade unions. In Serbia, the central role in this sphere was retained by the old trade union structures, while the newly established (minority) unions were concerned with the political task of fighting S. Milošević's regime (in cooperation with opposition parties) much more than with the recruitment of membership or the defense of the employees' economic interests (Arandarenko 1997). In Croatia, on the other hand, a fairly large number of new trade unions appeared, interlinked more firmly by their shared submission to the authoritarian regime than by mutual interest-based cooperation, which is why they were not capable of organizing wider collective actions for the protection of the workers' rights. Naturally, the inability of unions in both countries to organize collective action resulted in a huge drop in union membership to about a quarter (data for Croatia in Hodžić 2005a: 570, Table 3).

In the sphere of political organization, the political space on the left in Serbia was still monopolized by the formerly ruling communist party, which retained its control over the apparatuses of repression and mobilization, and

9 "Croatia is distinguished by a very high share of its population excluded from the work process. Compared with the initial period (1991), the number of pensioners almost doubled... and unemployment, with a rate of as high as $20 \%$, assumed structural characteristics." (Hodžić 2005b: 550) On privatization in Croatia during the 1990s, see Franičević 1999.

10 For the results of systemic research into the grey economy in Croatia in the mid and late 1990s, see Financijska teorija i praksa 1997, and Financijska teorija i praksa 2002. 
all attempts to form social-democratic parties to represent the workers' class interests ended in total failure. The situation in Croatia was different to the extent that the former communists were in opposition during the 1990s, and could therefore present themselves as (social-democratic) champions of the workers' interests. Naturally, when they took power in 2000 , it turned out that they essentially sought to implement a neo-liberal program of transformation ${ }^{11}$, while their "leftist" rhetoric successfully marginalized attempts at political organization of other left-wing parties.

Finally, the sudden and dramatic aggravation of the workers' economic position, in the absence of instruments for the formulation and expression of their collective interests (trade unions and political parties), obviously could not create a favorable environment for the formation of new (democratic, liberal/non-traditional, etc.) value orientations. This was made even more so, because the nationalist mobilization by the ruling regimes in a situation of civil war (and international pressures in Serbia) was necessarily highly efficient. Thus in both countries, exceptionally favorable conditions were created for the reproduction of forms of collectivist orientations (now on a partly changed, ethnic basis, strongly supported by the necessity for a central redistribution of income in a situation marked by mass pauperization, unemployment, etc.), as well as authoritarian and traditionalist values.

As is well known, Croatia and Bosnia and Herzegovina saw the end of the war in 1995, which shortly after brought Serbia to the end of its international isolation and economic recession. Overwhelming support in the country for the Milošević regime rapidly declined, and after the conflict with NATO countries concerning Kosovo in 1999, the old regime was finally removed in 2000 (for data on these and earlier elections see Antonić 2002). On the other hand, the death of Croatian president Tuđman enabled the replacement of the ruling party at the 1999 elections, whereby Croatia, politically speaking, adopted the typical transformation pattern of the former communists' return to power, followed by a periodic change of parties in the lead (Šiber 2006).

The process of economic transformation in both countries picked up speed after 2000, essentially following the (neoliberal) patterns applied in other postsocialist countries. This acceleration was particularly pronounced in Serbia, as it had been until then obviously far behind the others. Privatization gained momentum, the restructuring of the economic system was initiated (with the

\footnotetext{
11 Invoking representation of workers interests brought them a sudden increase in the number of workers' votes at the 1999 elections, but their neoliberal economic policy earned them, just as suddenly, a withdrawal of the workers support at the next elections in 2003. For data on the class vote in Croatia, see Šiber 2006: 329, Table 1.
} 
banking sector at the forefront in both processes), the economy was abruptly opened to the world, and foreign corporations entered with larger investments (participating in privatization more than in green-field investments). The state withdrawal from the economy was accompanied by the establishment of the appropriate normative order. Having strengthened legal regulation, the country's incorporation in the system of international trade and economic restructuring reduced the informal economy, and that together inevitably led to increased unemployment, bearing in mind that, the growth of national income notwithstanding, the previously low productivity, in addition to the closure of unsuccessful firms, also led to labor reductions in successful firms. Similar economic-systemic processes including GDP growth, the continuation of privatization and restructuring, the decline of the grey economy, along with increasing unemployment, were also found in Croatia. In a word, the market economy in both countries started to win primacy, both in ownership relations (due to the privatization of public enterprises and the increased number of domestic and foreign firms) and in regulatory terms (due to the substantially decreased redistributive role of the state and the legally secured autonomy of market laws), although the role of the state was still large in both spheres (some of the largest firms have not yet been privatized in Serbia, and have only been partly privatized in Croatia, with the law on revised privatization adopted in 2001: in Serbia, in the oil industry and in the production and distribution of electricity and telecommunications; in Croatia, in the oil and shipbuilding industries, etc; data for Serbia in Transparency Srbija 2004, and for Croatia in Franičević 2005). In the sphere of social relations, in addition to increased unemployment (which according to different estimates has a rate of $25-30 \%$ in Serbia and about $20 \%$ in Croatia), both these countries show an increase in inequality in earnings as well as in the overall income of different social groups. It is therefore obvious that the increased standard of living of the population is perceived as worthless by the majority of workers, in view of the insecurity of employment and growing income disparities between different classes and within the working class itself.

The strengthening of disintegrative forces (labor market, economic inequalities) was not accompanied by similar growth in opposite factors in either of these countries. The trade union movement in Serbia, which in the initial years after the establishment of the democratic order displayed some signs of revival, practically disappeared from the public scene after the 2003 elections: the old trade union organization was not transformed, the one established in the 1990s was not strengthened, and a third one did not appear. In Croatia, the union scene remained mutually divided into poorly coordinated and occasionally confronted organizations, which still included a clear 
minority of workers. The Serbian political scene witnessed the substantially declining influence of the Socialist Party, although unaccompanied by the rise of a social-democratic party. The SDP in Croatia was, during its first mandate in government (2000-2003), repeatedly accused of showing complete disregard for the interests of workers, and moreover did not publicly appear as the representative of this class for the next four years, until the elections became imminent. Finally, the unresolved state issue (related to the problem of Kosovo) still dominated public life in Serbia. In contrast, Croatia made advances in negotiations for its accession to the EU, and that is now presented as the immediately attainable objective of action.

Some of the analytical-historical inferences offered so far will be substantiated below with specific data, primarily those gathered in the abovementioned empirical surveys.

\section{SOCIAL MOBILITY OF THE WORKING CLASS, 1989-2003}

The importance of mobility for class formation had long been emphasized in theory and verified by research (Erikson - Goldthorpe 1992; Wright 1982). Research work into class mobility in Serbia and Croatia reveals an upward trend of social closure since the late 1970s, which placed the structures of these societies among the more rigid in the Central and Eastern Europe (CEE) region. Self-reproduction of the working class was, along with the selfreproduction of the middle class, the strongest factor for this rigidity (Lazić 1987; Cvejić 2006).

As we have seen, in 2003, Serbia and Croatia were, structurally and institutionally, substantially changed compared with 1989 , and the factors which had decisively influenced the position of the working class are clearly distinguishable. They are not related only to the transformation of the ownership sector and the transfer from the dominantly social to dominantly private ownership, nor to the emerging need for a different role of trade unions in the context of corporative negotiations and market strengthening. During the past ten or so years the economies of both countries also underwent structural transformation, following the trend noted in others CEE countries and revealed in the increasing takeover of the economic potential by the tertiary (and quaternary) sector compared with the primary and secondary sectors. ${ }^{12}$

\footnotetext{
12 GDP shares by sectors in 2005 , for Serbia and Croatia respectively were: primary - 16 and $7 \%$; secondary -33 and $31 \%$; and tertiary -51 and $62 \%$.

Cf. http://web.worldbank.org/WBSITE/EXTERNAL/DATASTATISTICS/
} 
Research data on intergenerational mobility show the activity of factors conducive to the dehomogenization of unskilled workers during the transformation in both countries (primarily, inflow of farmers in Serbia, and their increased inflow in Croatia in 2003) (Tables 1 and 2). In the case of skilled workers, certain contradictory tendencies were noted: the strengthening of homogeneity due to increased self-reproduction, and a substantially increased outflow towards routine clerks.

As for intragenerational mobility, it also reveals a contradictory tendency related to class homogeneity in both countries: intrastratal homogeneity decreases to a certain extent (in view of the increasing proportion of entries and exits from the groups of unskilled and skilled workers), but it is still possible to speak about the growing homogeneity of the working class as a whole, in view of the fact that the increased stratal circulation (at least partly) develops primarily between these two strata of manual workers (Table 3).

The analysis of intragenerational outflow mobility must be expanded, however, in view of the insufficient reliability of the data obtained so far as the result of the aforementioned, powerful trend of channeling a large part of Serbia's and Croatia's employed, faced with unemployment due to restructuring or privatization, towards the informal labor market (especially in Serbia), or retirement (especially in Croatia). Namely, with the breakdown of socialism, the overall integrative function of the socialist enterprise had to be replaced by other institutional mechanisms. In the initial period of transition this role should have been simultaneously and complimentarily taken over by the labor market and the state. The result of inefficient relations between these two institutions during the 1990s was the growth of the informal labor market (let us recall that at the height of the economic crisis in the mid-1990s, the grey economy reached $50 \%$ of GDP in Serbia and $25 \%$ in Croatia). In addition to the numerous standard categories of the unemployed, two other categories of the population were characteristic for this state of affairs, namely the seemingly employed and seemingly unemployed. The first category included those who were formally employed by a public (or even private) enterprise, but actually did not work or receive any income, except, at best, pension and health insurance contributions. The second category comprised those who were (and still are in large numbers) registered with national employment bureaus but informally worked for an employer or themselves. This institutional arrangement influenced the directions of working class structuring, which is why the analysis of mobility requires the inclusion of employment in the informal market as a career destination.

Another specific destination created for the members of the working class by the ruin of socialist enterprises, slow privatization, and inefficient state, 
was retirement. The number of disability and early retirements, suddenly increased as part of a special program in the restructuring and privatization of state enterprises (and in Croatia, additionally on the basis of participation in war), gave many workers the possibility to secure minimum social benefits and, at the same time, remain in the informal labor market, or turn toward the category of small farmers. For that reason we shall also analyze the workers' orientation towards early retirement.

In order to examine the career paths of a large number of workers who did not remain in the labor market, we shall compare the respondents' work place in 1989 and their social status in 2003. The list of social positions was formed by adding to the positions in the formal labor market (work place) categories of the unemployed, pensioners, and those employed in the informal market. The last category comprises all those who stated that they were unemployed but earned income from additional work (Table 4).

Presented in this way, the research findings best reveal the effects of the years of transformation. Naturally the most important finding is the large number of workers of both qualification levels who had to change their position compared with the beginning of the systemic changes, and that many of them in both countries ended in a position of dependence (from the state, as unemployed or retired, or from informal employers and whimsy informal markets). But, just as in the previous analysis, skilled workers are clearly in a better position than the unskilled. Not only have they managed to preserve their social position in larger percentages, but they are also substantially less exposed to unemployment than the unskilled workers (in Serbia), or the retired (in Croatia). Therefore, in addition to their overall influence on the fragmentation of the working class, by channeling its members toward different strategies of social reproduction, the weak institutions additionally intensify the already noted structural division of the unskilled and skilled groups.

In Serbia, unskilled workers remained in the labor market more, opting for either additional qualification or transfer to the grey market, while unskilled Croatian workers were more oriented towards social benefits (pension or unemployment). Skilled workers in Serbia were also found more in the labor market, either because they retained their position or joined the grey market. Croatian skilled workers were less oriented toward state benefits than the unskilled, but more so than Serbian skilled workers, primarily with respect to the status of the unemployed. These workers transferred to unskilled positions, or to routine non-manual positions more than Serbian skilled workers.

In sum, the analysis of class mobility shows that the structural basis for the fragmentation of the working class according to the qualifications criterion 
existed in 1989 and this fragmentation has meanwhile increased. The unskilled workers have a less stable recruitment pattern and career orientation. More than skilled workers, their fathers are farmers, and they remain less in their class group, being oriented toward skilled workers' occupations during their careers. This trend, however, places the group of qualified workers at the center, as the possible core for class constitution. This category is more consistently renewed in intergenerational terms and is more numerous with respect to intragenerational persistence. But the facts that affect the stability of the skilled workers' class position are important economic changes, as well as the economic crisis, which have pushed a good part of this group into unemployment, the informal market, or early retirement, thus reducing the basis for homogenization. It is important to note that although the prevailing trends in Serbia and Croatia differ in certain details, they share the same general orientation: increasing fragmentation on the whole, especially pronounced among unskilled workers, but also some tendencies with opposite effects among the skilled workers.

\section{ECONOMIC POSITION OF THE WORKING CLASS, 1989-2003}

The homogeneity of the working class' economic position was examined through the presence of economic inequalities. These inequalities were analyzed by means of a composite index of economic position. This index aggregates household scores from seven components: total income of the household; its ownership and the value of the real estate it uses; ownership and value of other real estate; infrastructural furnishings; individual housing equipment (household appliances, objects of art, etc.; means of production and auxiliary farm buildings); vacation destinations; and possession of car(s). All components are defined as discrete variables, considered on the basis of subjectively estimated market values, and the index of economic position is itself presented as a five-interval scale: low economic position, lower middle, middle, higher middle, and high economic position. ${ }^{13}$ Different economic position index scores of the unskilled and skilled workers are shown in the chart (Figure 1).

It is obvious that in 1989 both categories of workers in Serbia as well as in Croatia were below the economic position average for the sample, with a particularly less favorable relative economic position for unskilled workers in

13 For more details on forming the index, see Lazić - Cvejić 2006. 
Croatia. Although the differences between the two strata of manual workers are in both cases statistically significant (measured by t-test with significance level set at .000), it is obvious that the redistributive role of the state in Serbia was at that time already more pronounced. Similar relations were noted in 2003 , although the skilled workers in both states were then at the average level for the sample (and the difference between the two workers' strata remained significant). Naturally, the conspicuous overall economic lagging of Serbia during the 1990s is manifest in all categories observed. The lasting, substantially better economic position of skilled workers, therefore, confirms the existence of the previously noted structural basis for the fragmentation of the working class into a skilled and unskilled group.

\section{UNION AND POLITICAL ORGANIZATION AND VALUE ORIENTATIONS}

Trade union organization, as the institutional basis for class action formed on the basis of interests, was not measured in our 1989 research, for the simple reason that at that time all employees were formally union members. But as we have already mentioned, the social role of the trade unions of that time was to atomize the workers, rather than gather them, in view of the state's complete control over the single organization. The situation has now changed to the extent that the organization of unions is free, and both states already boast of a fair number of trade unions, although they still fail to formulate the workers' collective interest on a wider basis and to protect them through collective actions. That is clearly indicated by a dramatic drop in formal union membership of manual workers. Namely, according to our research data, only $15 \%$ each of skilled and unskilled workers in Serbia are union members today, while in Croatia $23 \%$ of skilled and $21 \%$ of unskilled workers have joined one of the trade union organizations (the overall sample of the employed here included $29 \%$ union members, only $10 \%$ of whom were active, while others declared themselves as "passive").

If the trade unions are incapable of overcoming the structural fragmentation of the working class (at least during the transformation), the question is whether there is a political party that could express its collective class interests. Judging by our research findings, one could hardly establish the existence of such a party in either Serbia or Croatia.

The thing that, in the political sense, kept workers of different qualifications in both countries together, not only during the civil wars dominated by nationalist mobilization, but to this very date, is the fact that they see the nationalist/populist 
parties as the best representatives of their interests. Thus, according to the 2003 survey, both groups of workers in Serbia supported the Serbian Radical Party (about $40 \%$ of unskilled workers who answered the question as to their political orientation compared with about $30 \%$ of skilled workers), and in Croatia, the Croatian Democratic Community (35\% of unskilled and $25 \%$ of skilled workers). However, even in this respect, a differentiation trend is noted. If all political parties are grouped into a, conditionally speaking, "nationalist bloc" (in Serbia: the coalition of the Serbian Radical Party, the Socialist Party of Serbia, and the Party of Serbian Unity, which formally existed in the Milošević regime; in Croatia: the Croatian Democratic Community/CDC, the Croatian Party of Law and other parties that support the CDC), and a "civic-democratic block" (in Serbia: the coalition of the Democratic Party, the Democratic Party of Serbia and G17 that formed the basis for political dominance after 2000; in Croatia: members of the coalition government in the 2000-2003 period - SDP, the Croatian Popular Party, the Istrian Democratic Union, etc. ${ }^{14}$ ), we may note the following difference in the distribution of the two different groups of workers, skill-wise, between these political options (Table 5).

We see that the "nationalist block" was dominant in Croatia in both categories of workers, and only among unskilled workers in Serbia; and also that in Croatia, skilled workers, substantially more than their unskilled colleagues, supported the "civic-democratic block". It is obvious that political fragmentation of the workers unfolded in both states, although through somewhat different mechanisms. In Croatia, ethnic mobilization atomized the workers with its totalizing approach, and persisted as the absolute center of political action, thus reducing the support to the Socialist Democratic Party which, at least formally, claimed to support the specific class interests. In Serbia, on the other hand, the political axis revolves around the problems related to the constitution of fundamental political (state and democratic) institutions, which is why a party that would thematize the workers' interests does not even exist in that sphere. Finally, a large difference in political orientations of unskilled and skilled workers, especially in Serbia, shows the absence of a factor that could potentially unite the two sub-groups of workers into a single social actor for the purposes of political representation.

Naturally, in addition to the structural-interest and institutional (organizational) aspect, a proper interpretation of possibilities for collective action requires an insight into the value orientations of the working class. Previous studies of value patterns of different social classes in Serbia revealed

14 Šiber differentiates political parties in Croatia as those of the left, center and right (cf. Šiber 2006: 327). In our classification, left and center are put together into civic-democratic block. 
obvious confusion in this respect. Members of the working class manifested below-average inclinations towards liberal values, i.e., an above average propensity for traditionalism, authoritarian orientation, and nationalism (similar findings were obtained for Croatia in 1989 - cf. Lazić ed. 1991). However, we should emphasize that at that time a slight difference between skilled and unskilled workers was also noted (Lazić-Cvejić 2004). For the purpose of examining value orientations in this analysis, we have constructed a scale of statist paternalism. This value pattern reveals an inclination towards egalitarianism and implies state intervention in reducing the economic differences and guaranteeing employment. This pattern is therefore directly opposed to decreasing the role of the state in the economy and society and may represent the basis for social action that would slow down social change, and in particular, interfere with the attempts to define the new role of the unions (the institution of collective bargaining as a new form of social dialogue that should replace the centralistic concept inherited from socialism) $)^{15}$.

Research findings give the following picture. Although in the period from 1989 to 2003 the awareness of the need for as little state intervention in the economy as possible increased in both strata of the working class, it was, on the other hand, accompanied by the decreasing conviction in the necessary advantage of private ownership for economic development. While the unskilled and skilled workers attitudes were, in 2003, equal in the first finding, the findings for the second show that skilled workers somewhat more frequently support the concept of private ownership, although they are still below the average for the sample of the total population. This allows the conclusion that in terms of its value orientations, the working class differs from the other social groups, but is, simultaneously, internally too divided to efficiently formulate a joint objective for political action. As for the statistpaternalistic value pattern, it is accepted by the workers to quite a high extent. On a scale of 4-20, where the lower score denotes higher acceptance of the pattern, the workers in Serbia and Croatia had an average score of 7. Such high acceptance of the paternalistic pattern, equal in both countries, leaves no room for fragmentation, but rather evidences the atomization of the working class, requiring external (which still means state) homogenization.

\footnotetext{
15 The scale of statist-paternalism comprises the following attitudes: "The Government is responsible for reducing income differences between those with high and low earnings;" "The Government should secure jobs for all who want them;" "The Government should guarantee a minimum living standard for all;" "The state should intervene in the economy in order to reduce inequalities and protect the poor and the weak" (the questions were identical for Serbia and Croatia). Cronbach's alpha for this scale is .83.
} 


\section{CONCLUSION: NEW SOURCES OF FRAGMENTATION?}

Our analysis has so far mostly addressed the traditional framework for the fragmentation of the working class, namely the level of qualifications. This conclusion will use the 2003 data in an attempt to show to what extent the modern form of economic transformation has contributed to the homogenization/fragmentation of the working class. We shall, therefore, examine the economic position, degree of union membership, political options, and value orientations of workers for disparities with respect to the sector (primary and secondary as opposed to the tertiary and quaternary) and the type of economy wherein the workers are engaged (state, private, "grey").

As for the differences in economic position, the score for the primary and secondary sectors in Serbia on the 1-5 scale is 2.07 , and 2.31 for the tertiary and quaternary sectors, compared with 3.00 and 3.52 , respectively, in Croatia, which in both cases show a statistically significant difference, indicating an additional source of the working class' fragmentation. The analysis by type of economy the workers are engaged in reveals an average score for the economic position index in Serbia's state sector of 2.00, followed by 2.11 for the "grey" sector, and 2.33 for the private, while the corresponding values for Croatia are $3.27,3.00$, and 3.27, respectively. ANOVA has established that workers in Serbia employed in the private sector have a statistically significantly better economic position than employees in the other two sectors, while this difference in Croatia is not statistically significant. This is, therefore, an additional source of fragmentation in Serbia, as opposed to Croatia.

In regards to trade unions, it is interesting that sectoral and ownership transformation of the economy has actually made their position in Serbia and Croatia inferior to the one they had toward the end of socialism. Namely, while $17 \%$ of workers in the primary and secondary sectors in Serbia are members of one union or another, this number is only $8 \%$ for those in the tertiary and quaternary sectors. By contrast, $18 \%$ of manual workers in Croatia are union members compared with $24 \%$ in the tertiary and quaternary sectors. In terms of ownership sectors, $17 \%$ of workers joined unions in the state sector, and $7 \%$ of those in the private sector, while the corresponding percentages for Croatia are $35 \%$ and $13 \%$. In other words, both structural and ownership changes in Serbia, for the time being, weaken union organization, while their effects in Croatia are quite the opposite. Adding to this the existence of a completely marginal presence of trade unions in the informal sector of economy, which is important for both these countries, it is made apparent that the unions cannot be expected to become a factor in overcoming working class segmentation in the forthcoming period. 
Assuming that a part of action energy of the working class could be transferred from trade union to political action, we should note a weak, but statistically significant link between the economic sector and political orientation in Serbia: employees in the tertiary and quaternary sectors vote for the parties of the "democratic block" somewhat more often $(45 \%)$ than those employed in the primary and secondary sectors (38\%). However, bearing in mind that this small difference does not detract from the support of the nationalist-populist block but rather from the following of other, smaller parties, we can fairly refer to the absence of political articulation that could overcome the workers fragmentation on the basis of their class interests (as opposed to ethnic homogenization). The same applies to the division by ownership sectors, since we have failed to establish any link between the political orientation of workers and their engagement in the state, private, or informal economy. Bearing in mind that in Croatia there are no differences in political orientations of the workers with respect to any of the examined dimensions, the previous conclusion is still more valid.

Finally, concerning the value patterns, we have seen that workers in both countries accept paternalism to such a high degree that it does not leave additional space for differentiation by economic sector or type of ownership. Further structural changes, therefore, will not by themselves eliminate the sources of fragmentation.

In most general terms, we may conclude that where post-socialist transformation and fragmentation of the workers are concerned, certain differences between Serbia and Croatia do exist, but their common elements still prevail. In both cases, transformation is accompanied by the working class's transfer from an atomized state, characteristic of socialism in a state of significant fragmentation. Thus, in Serbia, the basis for the differentiation of the workers' economic position is not only the level of their qualifications, but the type of ownership and specific economic sectors as well, which also introduce divisions within the category of skilled workers. The question is, however, whether the noted difference in economic position will be the actual obstacle to homogenization, or if the workers were to develop value orientations that may provide the framework for unified class action. The lacking element here is a more efficient organizational basis. The marginalization of union activism pushes all social goals of the working class into the political field, and then, in line with their value orientations, most workers, especially those with lower skills, support parties with egalitarian programs and populist rhetoric. The problem is that these political parties build their strength by encouraging nationalism and invoking the past, and are hardly at all 
turned towards the future and the modernization of the country, so that their political strengthening constantly slows down and endangers the process of transformation in Serbia and the country's firmer integration into European and world institutions.

The largest advance Croatia has made compared with Serbia has to do with the reduction of its grey economy and the elimination of differences in the economic positions of employees in the private and state sectors. Furthermore, its workers join the unions somewhat more, and the divisions along political lines are smaller than in Serbia. However, bearing in mind that the workers in Croatia give stronger support to the national-populist block than to the civic (and social democratic) one, their stronger unity is more of a source of atomization than the means for interest-based class homogenization. It is thus revealed that in Croatia as well there are a fair number of factors which make the fragmentation of the working class significant: in addition to value and political orientations, these include the larger exclusion of the workers from the labor market than in Serbia, smaller intergenerational and intragenerational self-reproduction, a difference in the degree of trade union membership among the workers employed in state and private firms, and differences in the economic position of those employed in different sectors of the economy. In a word, the process of transformation in Serbia and Croatia, instead of contributing to the class homogenization of the workers, has probably, by its having been interfered with, been caused to have its own pace slow down. Finally, we may assume that the process of European integrations will, in both cases, play an important role in both countries: that it will (externally) encourage both their transformation and their basic class homogenization. The key homogenizing factors should be the strengthening of the labor market, increased employment, and more significant trade union reform.

\section{REFERENCES}

Antonić, Slobodan (2002), Zarobljena zemlja. Srbija za vlade Slobodana Miloševića, Beograd, Otkrovenje

Arandarenko, Mihail (1997), Tržište rada u tranziciji: nastajanje industrijskih odnosa u Srbiji, Beograd, Ekonomski fakultet

Arzenšek, Vladimir (1984), Struktura i pokret, Beograd, Centar za filozofiju i društvenu teoriju

Berend, Ivan (1996), Central and Eastern Europe, 1944-1993, Cambridge, Cambridge University Press

Berković, Eva (1986), Socijalne nejednakosti u Jugoslaviji, Beograd, Ekonomika

CORVINUS JOURNAL OF SOCIOLOGY AND SOCIAL POLICY 1 (2010) 
Bolčić, Silvano (2002), "Rast privatnog sektora i preduzetništva u Srbiji", in Bolčić, Silvano - Andjelka Milić eds., Srbija krajem milenijuma, Beograd, ISI FF, pp. 107-122.

Cvejić, Slobodan (2000), "Opadanje društva u procesu dualnog strukturisanja društvena pokretljivost u Srbiji 90-ih”, in Lazić, Mladen ed., Račji hod, Beograd, Filip Višnjić, pp. 293-333.

Cvejić, Slobodan (2002), "Neformalna privreda u post-socijalističkoj transformaciji: 'Siva ekonomija' u Srbiji 90-ih", in Bolčić, Silvano \& Milić, Andjelka eds., Srbija krajem milenijuma, Beograd, ISI FF, pp. 123-140.

Cvejić, Slobodan (2006), Korak u mestu. Društvena pokretljivost u Srbiji u procesu post-socijalističke transformacije, Beograd, ISI FF

Čengić, Drago ed. (2005), Menadžersko-poduzetnička elita i modernizacija: razvojna ili rentijerska elita, Zagreb, Institut društvenih znanosti Ivo Pilar

Čučković, Nevenka (2002), "Siva ekonomija i proces privatizacije u Hrvatskoj, 19972001”, Financijska teorija i praksa Vol. XXVI, No. 1-2, pp. 245-272.

Erikson, Robert - John, H. Goldthorpe (1992), The Constant Flux, Oxford, Clarendon Press

Feher, Ferenc - Agnes Heller - Gyorgy Markus (1984), Dictatorship over Needs, Oxford: Basil Blackwell

Financijska teorija i praksa (1997), (tematski broj: Neslužbeno gospodarstvo u Republici Hrvatskoj) Vol. XXI, No. 1-2

Financijska teorija i praksa (2002), (tematski broj: Neslužbeno gospodarstvo u Republici Hrvatskoj) Vol. XXVI, No. 1-2

Franičević, Vojmir (1999), "Privatization in Croatia: Legacies and Context", Eastern European Economics Vol. 37, No. 2, pp. 5-54.

Franičević, Vojmir (2005), "Poduzetništvo i ekonomski rast u hrvatskom postsocijalističkom kontekstu“, in Čengić, Drago ed., Menadžersko-poduzetnička elita i modernizacija: razvojna ili rentijerska elita, Zagreb, Institut društvenih znanosti Ivo Pilar, pp. 169-210.

Hodžić, Alija (2005a), "Fleksibilizacija radnog procesa", Sociologija sela Vol. 43, No. 3, pp. 563-577.

Hodžić, Alija (2005b), "Društveno restrukturiranje i novi socijalni kontekst", Sociologija sela Vol. 43, No. 3, pp. 525-562.

Inglehart, Ronald (1997), Modernization and Post-modernization. Cultural, Economic and Political Change in 43 Societies, Princeton, NJ, Princeton University Press

Jovanov, Neca (1979), Radnički štrajkovi u SFRJ 1958-1969, Beograd, Zapis

Jovanov, Neca (1983), Dijagnoza samoupravljanja 1974-1981, Zagreb, Liber

Korošić, Marijan (1983), Ekonomske nejednakosti u jugoslavenskoj privredi, Zagreb, Liber

Lazić, Mladen (1987), U susret zatvorenom društvu, Zagreb, Naprijed

Lazić, Mladen ed. (1991), Položaj naroda i međunacionalni odnosi u Hrvatsko, Zagreb, IDIS

Lazić, Mladen ed. (1994), Razaranje društva, Beograd, Filip Višnjić

Lazić, Mladen (1996), "Delatni potencijal društvenih grupa“, Sociologija Vol. 38, No. 
2, pp. 259-288.

Lazić, Mladen ed. (2000), Račji hod, Beograd, Filip Višnjić

Lazić, Mladen (2000), "Elite u postsocijalističkoj transformaciji srpskog društva", in Lazić, Mladen, ed., Račji hod, Beograd, Filip Višnjić, pp. 21-64.

Lazić, Mladen - Slobodan Cvejić (2004), "Promene društvene strukture u Srbiji: slučaj blokirane post-socijalističke transformacije”, in Milić, Andjelka ed., Društvena transformacija i strategije društvenih grupa, Beograd, ISI FF, pp. 39-70.

Lazic, Mladen - Slobodan Cvejic (2006), "Changes in the Recruitment Patterns of the Economic and Political Elites in Serbia", Sociologija Vol. 48, No 2, pp. 97-112.

Lazic, Mladen - Slobodan Cvejic (2007), "Class and Values in Postsocialist Transformation in Serbia", International Journal of Sociology Vol. 37, No 3, pp. 54-74.

Madžar, Ljubomir (1990), Suton socijalističkih privreda, Beograd, Ekonomika

Milić, Andjelka ed. (2004), Društvena transformacija i strategije društvenih grupa, Beograd, ISI FF

Pantić, Dragomir (1977), "Vrednosti i ideološke orijentacije društvenih slojeva", in Popović, Mihailo, ed., Društveni slojevi i društvena svest Beograd, IDN, pp. 269406.

Pantić, Dragomir (1994), "A Review of Empirical Studies of Values in Yugoslavia", in Voich, Dan - Lee Stepina eds. Cross-Cultural Analysis of Values and Political Economy Issues, Westport, Conn. and London, Praeger, pp. 137-160.

Popović, Mihailo ed. (1987), Društvene nejednakosti, Beograd, ISI FF

Rus, Veljko - Frane Adam (1989), Moć i nemoć samoupravljanja, Zagreb, Globus

Sekelj, Laslo (1990), Jugoslavija - struktura raspadanja, Beograd, Rad

Sekulić, Duško (2004), Sukobi i tolerancija, Zagreb, Naklada Jesenski i Turk, HSD

Szelenyi Ivan - Szonja Szelenyi (1995), "Circulation or reproduction of elites during the post-communist transformation of Eastern Europe", Theory and Society Vol. 24, No. 5, pp. 615-638.

Šiber, Ivan (2006), "Političko ponašanje hrvatskih birača u izborima 1990-2003", in Lutovac, Zoran ed., Političke stranke i birači u državama bivše Jugoslavije, Beograd, Friedrich Ebert Stiftung, IDN, pp. 323-362.

Transparency Srbija (2004), Privatizacija - dokle se stiglo i kuda dalje?, Beograd, Libra

Wright, Erik Olin (1985), Classes, London, Verso

Županov, Josip (1983), Samoupravljanje i društvena moć, Zagreb, Globus 
Table 1 Intergenerational social mobility of the working class, 1989-2003: inflow

\begin{tabular}{|c|c|c|c|c|}
\hline \multirow[t]{2}{*}{ Year } & \multirow[t]{2}{*}{ Father's class position } & \multicolumn{2}{|c|}{$\begin{array}{l}\text { Inflow mobility rate } \\
\qquad(\%)\end{array}$} & \multirow{2}{*}{$\begin{array}{c}\text { Respondent's class } \\
\text { position }\end{array}$} \\
\hline & & Serbia & Croatia & \\
\hline \multirow{4}{*}{1989} & Farmer & 47 & 24 & \multirow{8}{*}{$\begin{array}{l}\text { UNSKILLED } \\
\text { MANUAL } \\
\text { WORKER }\end{array}$} \\
\hline & Unskilled manual worker & 23 & 34 & \\
\hline & Skilled manual worker & 14 & 21 & \\
\hline & Unskilled non-manual worker & 2 & 2 & \\
\hline \multirow{4}{*}{2003} & Farmer & 43 & 42 & \\
\hline & Unskilled manual worker & 32 & 36 & \\
\hline & Skilled manual worker & 13 & 14 & \\
\hline & Unskilled non-manual worker & 2 & 2 & \\
\hline \multirow{4}{*}{1989} & Farmer & 34 & 21 & \multirow{8}{*}{$\begin{array}{l}\text { SKILLED } \\
\text { MANUAL } \\
\text { WORKER }\end{array}$} \\
\hline & Unskilled manual worker & 16 & 24 & \\
\hline & Skilled manual worker & 28 & 31 & \\
\hline & Unskilled non-manual worker & 4 & 2 & \\
\hline \multirow{4}{*}{2003} & Farmer & 28 & 18 & \\
\hline & Unskilled manual worker & 26 & 30 & \\
\hline & Skilled manual worker & 29 & 33 & \\
\hline & Unskilled non-manual worker & 5 & 5 & \\
\hline
\end{tabular}

CORVINUS JOURNAL OF SOCIOLOGY AND SOCIAL POLICY 1 (2010) 
Table 2 Intergenerational social mobility of the working class, 1989-2003: outflow

\begin{tabular}{|c|c|c|c|c|}
\hline \multirow[t]{2}{*}{$\begin{array}{l}\text { Father's class } \\
\text { position }\end{array}$} & \multicolumn{2}{|c|}{$\begin{array}{c}\text { Outflow mobility } \\
\text { rate }(\%)\end{array}$} & \multirow[t]{2}{*}{ Respondent's class position } & \multirow[t]{2}{*}{ Year } \\
\hline & Serbia & Croatia & & \\
\hline \multirow{8}{*}{$\begin{array}{l}\text { UNSKILLED } \\
\text { MANUAL } \\
\text { WORKER }\end{array}$} & 11 & 6 & Farmer & \multirow{4}{*}{1989} \\
\hline & 18 & 19 & Unskilled manual worker & \\
\hline & 31 & 39 & Skilled manual worker & \\
\hline & 9 & 8 & Unskilled non-manual worker & \\
\hline & 3 & 3 & Farmer & \multirow{4}{*}{2003} \\
\hline & 20 & 21 & Unskilled manual worker & \\
\hline & 30 & 39 & Skilled manual worker & \\
\hline & 12 & 8 & Unskilled non-manual worker & \\
\hline \multirow{8}{*}{$\begin{array}{l}\text { SKILLED } \\
\text { MANUAL } \\
\text { WORKER }\end{array}$} & 5 & 2 & Farmer & \multirow{4}{*}{1989} \\
\hline & 7 & 9 & Unskilled manual worker & \\
\hline & 33 & 39 & Skilled manual worker & \\
\hline & 13 & 9 & Unskilled non-manual worker & \\
\hline & 1 & $*$ & Farmer & \multirow{4}{*}{2003} \\
\hline & 7 & 7 & Unskilled manual worker & \\
\hline & 32 & 38 & Skilled manual worker & \\
\hline & 19 & 28 & Unskilled non-manual worker & \\
\hline
\end{tabular}


Table 3 Intragenerational social mobility of the working class, 1989-2003: inflow

\begin{tabular}{|c|c|c|c|c|}
\hline \multirow[t]{2}{*}{ Year } & \multirow[t]{2}{*}{ Father's class position } & \multicolumn{2}{|c|}{$\begin{array}{l}\text { Inflow mobility rate } \\
\qquad(\%)\end{array}$} & \multirow{2}{*}{$\begin{array}{c}\text { Respondent's class } \\
\text { position }\end{array}$} \\
\hline & & Serbia & Croatia & \\
\hline \multirow{4}{*}{1989} & Farmer & 1 & 1 & \multirow{8}{*}{$\begin{array}{l}\text { UNSKILLED } \\
\text { MANUAL } \\
\text { WORKER }\end{array}$} \\
\hline & Unskilled manual worker & 96 & 91 & \\
\hline & Skilled manual worker & 1 & 4 & \\
\hline & Unskilled non-manual worker & 1 & $*$ & \\
\hline \multirow{4}{*}{2003} & Farmer & 3 & 4 & \\
\hline & Unskilled manual worker & 89 & 72 & \\
\hline & Skilled manual worker & 3 & 17 & \\
\hline & Unskilled non-manual worker & 1 & 2 & \\
\hline \multirow{4}{*}{1989} & Farmer & $*$ & $*$ & \multirow{8}{*}{$\begin{array}{l}\text { SKILLED } \\
\text { MANUAL } \\
\text { WORKER }\end{array}$} \\
\hline & Unskilled manual worker & 8 & 18 & \\
\hline & Skilled manual worker & 88 & 78 & \\
\hline & Unskilled non-manual worker & 1 & 1 & \\
\hline \multirow{4}{*}{2003} & Farmer & 1 & * & \\
\hline & Unskilled manual worker & 20 & 12 & \\
\hline & Skilled manual worker & 74 & 76 & \\
\hline & Unskilled non-manual worker & 3 & 4 & \\
\hline
\end{tabular}

Table 4 Change of social position of manual workers in Serbia and Croatia, 1989-2003, by percentage

\begin{tabular}{lcccc}
\hline \multirow{2}{*}{ Social position in 2003 } & \multicolumn{4}{c}{ Class position in 1989 } \\
\cline { 2 - 5 } & Unskilled manual worker & Skilled manual worker \\
\cline { 2 - 5 } & Serbia & Croatia & Serbia & Croatia \\
\hline Unskilled manual worker & 23 & 23 & 1 & 6 \\
Skilled manual worker & 15 & 6 & 44 & 32 \\
Unskilled non-manual worker & 2 & 1 & 3 & 6 \\
Farmer & 2 & $*$ & 1 & $*$ \\
Informally employed & 10 & 4 & 9 & 2 \\
Unemployed & 10 & 16 & 4 & 16 \\
Retired & 33 & 47 & 30 & 31 \\
\hline
\end{tabular}

CORVINUS JOURNAL OF SOCIOLOGY AND SOCIAL POLICY 1 (2010) 
Table 5 Voting preferences of manual workers in Serbia and Croatia in 2003, by percentage

\begin{tabular}{lcccccc}
\hline & \multicolumn{3}{c}{ Political option (voting preference) } \\
\cline { 2 - 6 } Category of worker & \multicolumn{3}{c}{ Nationalistic block } & $\begin{array}{c}\text { Civic-democratic } \\
\text { block }\end{array}$ & $\begin{array}{c}\text { Other political } \\
\text { parties }\end{array}$ \\
\hline \multirow{3}{*}{ Unskilled } & Serbia & Croatia & Serbia & Croatia & Serbia & Croatia \\
Skilled & 50 & 64 & 32 & 33 & 18 & 3 \\
\hline
\end{tabular}

Figure 1 Economic position of working class, Serbia and Croatia, 1989-2003

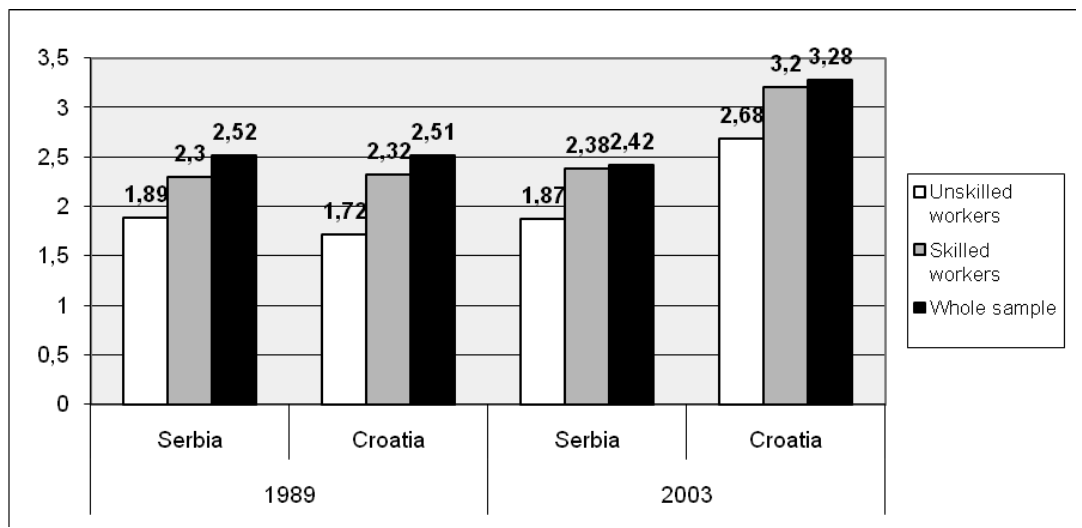

CORVINUS JOURNAL OF SOCIOLOGY AND SOCIAL POLICY 1 (2010) 